\title{
"a sutte of black which will always be of use to you": Expressions of Difference and Similarity in the Clothing Choices of the Scottish Male Elite Travelling in Europe, 1550-1750
}

\begin{abstract}
Some of the Scottish soldiers who fought for Gustavus Adolphus during the Thirty Years' War wore their national dress. While very distinctive, their clothing was not representative of that chosen by many of the Scottish men living in Europe. Having left their homeland for reasons of trade, education, leisure, or exile, their fashionable clothing was carefully selected to ensure that they integrated into the societies they visited. Taking the fashion advice of Andrew Fletcher of Saltoun and the letters and accounts of Robert, lord Kerr of Newbattle and his younger brother William as two small case studies, this article explores how elite Scottish men used black clothing, as a staple component of their travel wardrobe, because black was socially acceptable throughout Europe. Their choices abroad will be contextualized by their choices at home, those made by English men, and the guidance offered by Baldassare Castiglione that transcended national boundaries.
\end{abstract}

\section{Introduction}

Men, dressed in black "suits", consisting of doublet, hose and gown, or coat, waistcoat and breeches, were a familiar sight throughout Western Europe in the sixteenth and seventeenth centuries. ${ }^{1}$ Their black garments conveyed multiple meanings that were linked to the wearer's age, social status, location, disposable income, and their religion. ${ }^{2}$ Indeed, it was the ubiquity and adaptability of the black suit that made it a staple item in the wardrobes of early modern men of means as an item of fashion as well as for mourning. Indeed, as Elizabeth Currie has shown, secular Florentine men used black as an expression of their civic, mercantile, and courtly personas, identities that ran alongside those of the lower

1 For a very clear analysis of seventeenth century Stuart dress, see Aileen Ribeiro: Fashion and Fiction. Dress in Art and Literature in Stuart England. New Haven 2005.

2 John Harvey: The Story of Black. London 2013.

Ә Open Access. () 2019 Maria Hayward, published by De Gruyter. (cc) BY-NC-ND This work is licensed under a Creative Commons Attribution-NonCommercial-NoDerivatives 4.0 International License.

https://doi.org/10.1515/9783110635942-003 
ranks of black clad clergy. ${ }^{3}$ However, as the Florentine example hints at, one man's desirable black suit was something in which another would not be seen out of doors. In other words, the devil was in the detail, and the subtle but very significant details of each suit included the type of fabric used, the quality of the black, the cut, and the use, or not, of trimmings. When combined, these factors made a world of difference between a fashionable suit and one that lacked distinction on all fronts. These clothes also conveyed ideas about the nationality of the wearer, or rather where the suit had been made, because to the well-trained eye there were noticeable differences in cut and underlying attitudes between a "haughty" Spanish black suit and a "civic" suit at home in one of the Italian city states, for example. ${ }^{4}$ With this in mind, this article will consider, through three short case studies, the role of the black suit in the luggage of members of the Scottish male elite travelling in Europe. These men will be contextualized by reference to a wider circle of English men and Scots who stayed at home.

The questions explored in the case studies are drawn from the English edition of Baldassare Castiglione's Il Cortegiano or The Book of the Courtier. Born in Mantua, Castiglione (1478-1529), was a diplomat, scholar and soldier and his book of advice on how to be a courtier was highly influential throughout Europe. When Sir Thomas Hoby published his translation in 1561, he made Castiglione's ideas accessible to the English-speaking/reading world. ${ }^{5}$ Castiglione stated that the clothing of the courtier should be:

rather somewhat grave and auncient, than garish. Therefore me thinke a blacke colour hath a better grace in garments, than any other, and though not thoroughly blacke, yet somewhat darke, and this I mean for his ordinarie apparell. ${ }^{6}$

This courtly grace is evident in Castiglione's portrait. Painted by Raphael in 1514-15, Castiglione followed his own advice and was elegantly dressed in black, grey and white. ${ }^{7}$ While not all of the men under consideration here were "courtiers", Castiglione's three key points were applicable to a much broader section of society: that black was suitable for everyday or "ordinary" wear, that it was not just black but also included "somewhat dark" shades and that its virtues were expressed in specific terms - namely "somewhat grave and auncient”, meaning

3 Elizabeth Currie: Fashion and Masculinity in Renaissance Florence. London 2016, 108.

4 Ibid., 105-106.

5 Mary Partridge: Thomas Hoby's English translation of Castiglione's Book of the Courtier, in: The Historical Journal 50 (2007), 769-786.

6 Baldassare Castiglione: The Book of the Courtier, trans. by Sir Thomas Hoby, 1561, ed. by J. H. Whitfield. London 1974, 116.

7 Raphael: Baldassare Castiglione, 1514-1515, oil on panel, 82 x 67 cm, Louvre, Paris, no. 611. 
sober, rather than "garish". This article does not follow the view presented by Michel Pastoureau that there was Protestant "chromoclasm" that reflected their wish for sobriety. ${ }^{8}$ While many Scottish Presbyterians were painted in black, their bills and accounts indicate that they owned colored clothing too. ${ }^{9}$ Equally, Scottish Catholics, like their European counterparts also favored black on occasion. ${ }^{10}$ Black straddled the confessional divide and other considerations were important including being in fashion if the occasion required a particular sartorial display and looking like you were part of the society that you were living amongst.

The fashionability of the black suit was closely linked to where it was worn, and where it was scrutinized by observers. As the merchant-adventurer Marmaduke Rawdon (1583-1646) observed, when he bought new clothes for a visit to London in the early 1630s, after he had traveled abroad "he was to be clothed after the English fashion which was then blacke cloothes."11 If black was a noticeable color choice in the 1630s, by the 1660s it was the cut that gave clothes a London look, as is evident when Sir Gideon Scott of Highchester wrote to his son William, the earl of Tarras, on 9 June 1664, saying that he was sending him clothes from London noting that "everie thing is just in fashione thoughe they may seeme strange to yow." choice of the word "strange" indicates he was very conscious of a difference between London and Scotland. "Strange" was the word that the diarist Samuel Pepys used when he described the visit of the French ambassador, Jean-Baptiste Colbert (1619-1683), to London four years later in August 1668. The Frenchman was "a comely man, and in a black suit and cloak of silk; which is a strange fashion now, it hath been so long left off'. ${ }^{13}$ Here strange, or as is implied, old-fashioned, was not a desirable quality in a man's wardrobe, especially when that man was representing his country. The style in question may well have been that depicted by Claude Lefèbvre in 1666, and this example highlights the ways in which fashionable clothing did, or in this case did not, successfully cross national borders. ${ }^{14}$

8 Michel Pastoureau: Black. The History of a Color. Princeton 2008, 124; Hilary Larkin: The Making of Englishmen. Debates on National Identity 1550-1650. Leiden 2014, 96.

9 Rosalind. K. Marshall: Conscience and Costume in Seventeenth-Century Scotland, in: Costume 6 (1972), 33.

10 José Luis Colomer: Black and the Royal Image, in: José Luis Colomer and Amalia Descalzo (eds.): Spanish Fashion at the Courts of Early Modern Europe, vol. 1. London 2012, 77-112.

11 Robert Davis (ed.): The Life of Marmaduke Rawdon of Yorke. London 1863, 24.

12 Sir Gideon Scott to Tarras, his son, London, 9 June 1664, GD157/2123 (National Records of Scotland).

13 Robert Latham and William Matthews (eds.): The Diary of Samuel Pepys, 11 vols. London 1983, vol. 9, 284.

14 Claude Lefèbvre: Jean-Baptiste Colbert, 1666, oil on canvas, Palace of Versailles, inv. no. 2187. 


\section{Black in Scottish Society}

When looked at as a group, portraits of early modern Scottish men reveal a sizeable number of black-clad men such as James Stuart, duke of Richmond and Lennox, dressed in a black doublet, breeches, and cloak (Figure 1). Other examples include George, first earl of Kinnoull, in his black full-length gown, symbol of his office as Lord Chancellor of Scotland (1633), James, third marquis of Hamilton, all in black satin in 1643, a choice that Rosalind Marshall attributes to personal grief and sorrow at the Stuarts' three kingdoms being at war and the sober black cloth of Archibald, first marquis of Argyll (1656). ${ }^{15}$ However, while black was

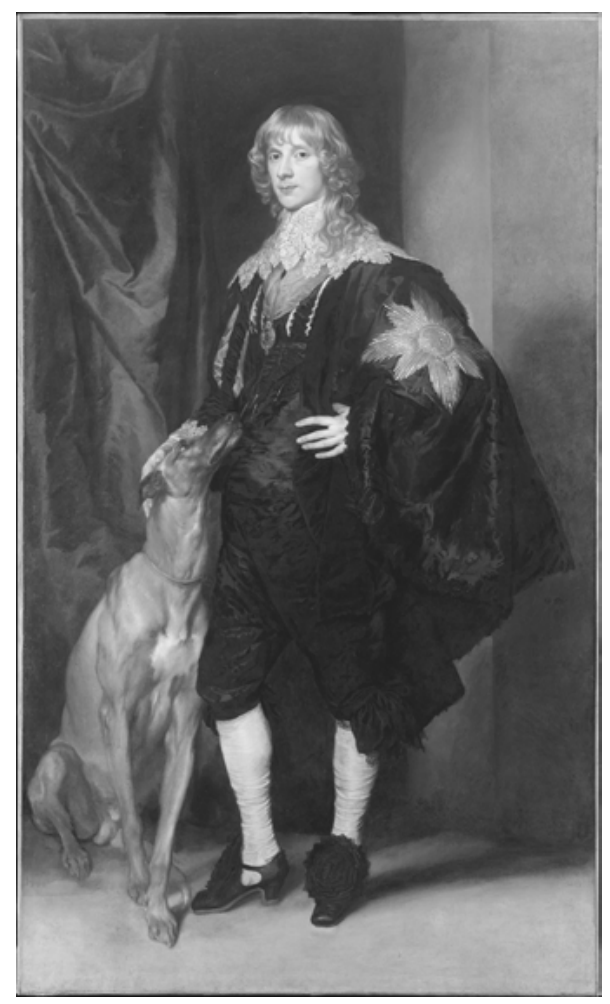

Figure 1: Sir Antony van Dyck: James Stuart, Duke of Richmond and Lennox, c. 1633-35, oil on canvas, $215.9 \times 127.6 \mathrm{~cm}$, Metropolitan Museum of Art, New York, Marquand Collection, Gift of Henry G. Marquand, 1889, acc. no 89.15.16.

15 Rosalind Marshall: Costume in Scottish Portraits 1560-1830. Edinburgh 1986, 16-18. 
a frequent choice, it was not the only choice made by Scottish men as the silver camlet suit selected by third marquis of Hamilton in 1629 or the coat and vest, adorned with ribbon and braid, worn proudly by John, first duke of Rothes in 1667. ${ }^{16}$ Each portrait offers just one glimpse into the sitter's wardrobe, but what they strongly suggest is that for elite Scottish men, black clothes and robes played an important but not necessarily dominant part in their clothing choices. Indeed, as Keith Brown has observed the Scottish elite spent heavily on their clothes, with the heir of the fifth earl Marischal, Lord Keith, spending $£ 2,448$ on clothing in 1610 . $^{17}$

For those shopping for black fabric in sixteenth-century Scotland a range of different qualities were available as indicated by a list of clothing stolen by Thomas Charteris of Kinfawnis and John Charteris of Cuthilgurdy from John Moncur of Ballumy in September 1544. Their haul included a doublet of black worsted containing three ells, five pairs of black hose, a "hugtoun" coat (a short sleeveless coat) of Paris black walit (guarded) with velvet, a gown of French black lined with budge, a single gown of black, and a riding coat of Scots black lined with black gray. ${ }^{18}$ The funeral preparations for James V of Scotland (1512-1542) reveal a similar range of choice, with the French and Paris blacks being more expensive than the Scottish versions. ${ }^{19}$ Thus black fabrics crossed national borders, carrying with them associations of cost and quality.

These black materials were regularly incorporated into men's everyday wardrobes, as in the case of the doublet and breeks (breeches) of black satin that George Oustine, merchant and burgess of Edinburgh, made for Colin Campbell, fiar of Glenorchy, in $1606 .{ }^{20}$ Black clothing was also valued enough to be left as bequests, and in 1623 John, second lord Madertie, discharged his brother Sir James Drummond of Machanie, of a range of items including a doublet and breeks of black satin and a two-handed sword. ${ }^{21}$ The black was put to a range of other

16 Ibid., 15, 19.

17 Keith Brown: Noble Society in Scotland. Wealth, Family and Culture, from Reformation to Revolution. Edinburgh, 2004, 83.

18 Signet letters of apprising against Thomas Charteris of Kinfawnis and John Charteris of Cuthilgurdy, who have stolen goods from John Moncur of Ballumy, from his lands of Knokhill in September 1544, GD112/3/18 (National Records of Scotland).

19 Sir James Balfour Paul (ed.): Accounts of the Lord High Treasurer of Scotland, vol. 8: 1541-1546. Edinburgh 1908, 142-146.

20 Discharge by George Oustine, merchant, burgess of Edinburgh, to Colin Campbell, fiar of Glenurquhay, of $£ 116$ in complete payment of all accounts and merchandise furnished, 12 November 1613, GD112/23/7, no. 12 (National Records of Scotland).

21 Discharge by John, 2nd lord Madertie, to Sir James Drummond of Machanie, kt., his brother, of heirship, 3 November 1623, RH15/123/1 (National Records of Scotland). 
uses too, including official black robes that marked out state officials. In August 1668 the advocate James Cumming bought a black velvet gown laced with gold lace and trimmed with gold embroidered buttons and loops for the marquis of Montrose. ${ }^{22}$ Black was also used for clerical dress, as is revealed in a letter sent by James Strachauchin, parson of Fethercarne, to Thomas Strathauchin of Carmly, in the mid-sixteenth century (and so just prior to the Reformation in Scotland) asking for his black gown, vestments, and silver chalice. ${ }^{23}$

European ways of using black were on show in Scotland, as in September 1508 when the divine and historian, David Calderwood (1575-1650), recalled the arrival of Ulrich, duke of Württemberg (1487-1550). The duke was:

a young man of comelie behaviour, accompanied with twenty-foure in traine, came to see the countrie. He was convoyed from place to place by noblemen, by the king's directioun, and weill interteaned. His traine were all clothed in blacke. ${ }^{24}$

As John McGavin has noted, this represents a sobriety in dress of which Calderwood would have approved. As such, it was a style more usually expected from clergy in Scotland, and unlikely to be adopted by the high-ranking Scots nobility unless they were in mourning. ${ }^{25}$

\section{Scottish Alternatives to Fashionable Black}

Some of the Scottish soldiers who fought for Gustavus Adolphus, king of Sweden (1594-1632), during the Thirty Years' War wore their national dress. ${ }^{26}$ This style, including a plaid and bonnet, was captured in a woodcut of $1631 .^{27}$ While very distinctive, these soldiers were not representative of all Scots, and there were attempts to regulate this style. Many, especially those from the middling sort and

22 Sundry small accounts of the family of Montrose discharged, 4 August 1668, GD220/6/748, no. 16 (National Records of Scotland).

23 Letter to Thomas Strathauchin of Carmly from Mr. James Strachauchin parson of Fethercarne, 21 May, no year but mid-sixteenth century, GD45/14/779 (National Records of Scotland).

24 David Calderwood: The History of the Kirk of Scotland, ed. by Thomas Thomson, vol. 6. Edinburgh 1845, 783.

25 I am very grateful to Professor John McGavin for this reference and insight.

26 Henry McClintock: Old Highland Dress and Tartans, 2nd ed. Dundalk 1949 and id.: Old Irish and Highland Dress. Dundalk 1950.

27 Unknown artist: Scottish Soldiers in the Service of Gustavus Adolphus, 1631, woodcut, New York Public Library Digital Collections, PC ARMY-(M-Z). 
elite, favored fashionable dress for everyday wear. While hunting, however, the elite often wore more traditional clothing and by the 1670 s the plaid was worn with a short-waisted doublet of a style that had dropped out of fashion in the 1660 s. $^{28}$

By the early eighteenth century, the Jacobite supporters of the exiled Stuart kings, began to favor wearing the plaid as a sign of their support for the "king over the water". However, Vicci Coltman has noted that while much has been made of Bonnie Prince Charlie (1720-1780) actively wearing tartan to stress his ties to Scotland during his campaign to recover his throne in 1745-1746, he did not always wear it, citing his appearance on 29 July 1745 . For his first meetings in Scotland, the prince was dressed in:

a plain black coat with a plain shirt not very clean and a cambric stock fixed with a plain silver buckle, a fair round wig out of the buckle, a plain hatt [...] he had black stockings and brass buckles in his shoes. ${ }^{29}$

However, the context for this black suit was very significant because Charles Edward Stuart was travelling incognito in his bid to rally support in Scotland. As Alexander MacDonald of Glenaladale recalled, "we were immediately told [...] that this youth was also ane English clergyman who had long been possess'd with a desire to see and converse with Highlanders." 30 These simple black clothes made the prince look the part, but, as Jacqueline Riding has noted, his real identity was given away by how people who knew who he was behaved towards him. ${ }^{31}$

\section{Reasons for Travel}

Some Scots left their homeland because of economic opportunities or necessity, but this was not the motivation for the group under consideration here.

28 See, for example, John Michael Wright: Lord Mungo Murray [Am Morair Mungo Moireach], 1683, oil on canvas, $88^{1 / 2} \times 603 / 4$ inches $(224.8 \times 154.3 \mathrm{~cm})$, National Galleries of Scotland, PG 997.

29 George Lockhart Esq. of Carnwath: The Lockhart Papers, vol. 2. London 1817, 480; Viccy Coltman: Party-coloured Plaid? Portraits of Eighteenth-Century Scots in Tartan, in: Textile History 41 (2010), 213. Also see Robin Nicholson: The Tartan Portraits of Prince Charles Edward Stuart. Identity and Iconography, in: British Journal for Eighteenth Century Studies 21 (1998), 145-160.

30 Jacqueline Riding: Jacobites. A New History of the '45 Rebellion. London 2016, 85.

31 Ibid., 85. 
Their reasons for heading to Europe included education and learning how to be a gentleman, as is indicated by the letter of advice sent by Sir Robert Gordon (1580-1656) to his nephew, the eleven-year-old John, fourteenth earl of Sutherland, c. 1620. Sir Robert was certain that "Ther can be no accomplished gentleman without travelling abrod in other kingdomes." 32 This idea held true into the second half of the century. In 1661 the marquis of Argyll noted that "he that hath lived lock'd up in one Kingdom" was "but a degree beyond a Countryman, who was never put out of the bounds of his parish." 33 With this thought in mind, William Moncreif wrote from Versailles to the laird of Blair Drummond, younger, on 3 July 1699, describing the proposed route for a grand tour that Lord Hay wished to join. ${ }^{34}$ Alternatively men traveled for the sake of their health, as in the case of Robert, earl of Lothian, who was granted a license to travel to Spa in the Low Countries, or "to any other suitable place, [and] there to remain for a year for recovery of his health". ${ }^{35}$ Others sought a military career, or a life in trade, or both, as in the case of James Spens who wrote to his parents who lived on the Canongate in Edinburgh on 12 November 1631 informing them that he had taken his discharge from Spens of Wormiston and left the king of Sweden's service. He had gone to Holland but now planned to travel for seven years in the East Indies with Bessie Cowan's son, George Borthwick. ${ }^{36}$ In all of these examples, the men were often away for long periods of time, meaning that they might spend weeks or months in the same place so their appearance was important, making a lasting impression of those they met and stayed with.

Travel writing, whether in the form of journals, letters, or accounts, provides evidence of how individuals encountered and responded to national difference. ${ }^{37}$ Clothing often played a key role in this. It might be when they encountered unfamiliar clothes, such as when the Presbyterian, William, earl of Lothian, visited the

32 Sir William Fraser (ed.): The Sutherland Book, vol. 2: Correspondence. Edinburgh 1892, 365. 33 Archibald Campbell: Instructions to a Son. London 1661, 72; Claire Jackson: Restoration Scotland, 1660-1690. Royalist Politics, Religion and Ideas. Woodbridge 2003, 31.

34 Letters (5) addressed to the laird of Blairdrummond and others, 1693-1699, GD24/1/471, fols. 3-4 (National Records of Scotland).

35 Licence to Robert, Earl of Lothian, to travel to Spa in the Low Countries or to any other suitable place, there to remain for a year for recovery of his health, 1609-1624, GD40/2/19/1/5 (National Records of Scotland).

36 James Spens, son of James Spens, Edinburgh. To his mother and father, addressed to his mother in Canongate beneath the cross above John Ramsay's land, 12 November 1631, RH9/2/ 241 (National Records of Scotland).

37 John McGavin: Thomas Ker of Reddon's Trip to the Low Countries, 1620, in: Sarah Carpenter and Sarah Dunnigan (eds.): Joyous Sweit Imaginatioun. Essays on Scottish Literature in Honour of R. D. S. Jack. Amsterdam 2007, 157-159. 
sisters of the Catholic eighth marquis of Argyll. The three women had become nuns and lived in Antwerp, Brussels, and Lothian, and they carefully recorded the different colors of their habits. ${ }^{38}$ For Scots going into exile in Europe, their clothes often indicated how they integrated themselves into their new lives. The travel account books of David Melville, third earl of Leven (1660-1728), which cover the period from 1684-1686 when he was in exile, reveal a man with money to spend adapting to life in a new country. Resident in the Low Countries because of his involvement in the Rye House plot to kill Charles II and his younger brother, James duke of York and Albany, Melville proved himself a loyal supporter of William of Orange. While he was a Presbyterian, he recorded very little detail about the color of his clothing purchases that were bought locally, with the exception of a pair of black fringed gloves and a pair of black silk stockings. ${ }^{39}$ A similar theme runs through the accounts of Sir David Nairne (1655-1740), who accompanied James VII and II (1633-1701) into exile, and worked as clerk of the foreign office at St Germain. Nairne dressed carefully yet elegantly in the French style: on 6 November 1699 he bought himself a black coat and breeches, in October 1702 he spent £58 14s on a new sword and a new suit, and on 25 January 1697 and 6 January 1700 he bought new wigs costing 39 livres and 52 livres, respectively. ${ }^{40}$ For both men, black remained an integral part of their new wardrobes as they adapted to life away from Scotland.

\section{The Virtue of Black According to Andrew Fletcher}

It is in the letters of the first case study, Andrew Fletcher of Saltoun, East Lothian (1655-1716) - a writer, politician, and opponent of the 1707 act of Union between Scotland and England - that the need for a black suit was seen to be so important. ${ }^{41}$ He gave this advice to his nephew Andrew, who was studying in Leiden before he traveled to Paris to meet his uncle in 1716. Fletcher's advice focused on three key points. Firstly, that "black cloath [...] will always be of good use to you and save you the trouble of making a sutte

38 Travel journal of William, Earl of Lothian, no year, 30 March/9 April to 2 March/12 April, GD40/15/58, (National Records of Scotland).

39 Note-book containing personal accounts of the Earl of Leven while in the Low Countries, 1684-1686, un-paginated, GD26/6/139 (National Records of Scotland).

40 Edward Corp: A Court in Exile. The Stuarts in France, 1689-1718. Cambridge 2009, 148.

41 Irene J. Murray: Letters of Andrew Fletcher of Saltoun and His Family, 1715-1716, in: Scottish History Society, 4th series, vol. 2, Miscellany 10. Edinburgh 1965, 145-173. For the wider context see Paul H. Scott: Andrew Fletcher and the Treaty of the Union. Edinburgh 1992. 
immediately upon your coming to town." Secondly, that black was a sound choice for travel clothes on this occasion because "There is no hazard of traveling with a black suttee since you go not a horseback." 42 However, "It were redicoulous for you to post from thence since it is but the gaining of 3 days and will spoyle your black suttee." 43 Thirdly, that black had the added virtue of being able to serve as mourning as well as fashionable dress so that those who do not dress in black "will be in good pickle and must at least wait 3 days in their chamber to cloathes". The clever compromise was to have the suit made in advance to his uncle's specifications:

There is no alteration in the fashion of the coat but that the slive must not be as mine was made [diagram] but thus [diagram]. This is the outside of the flap [diagram] others cut it thus [diagram] but the best is to make it very large and then if there be any alteration it is easily mended. ${ }^{44}$

So, with careful planning, a black suit made in Leiden could be made in the style that fulfilled all of the subtle details of a Parisian suit, ensuring its wearer immediate access to French society. While Fletcher was evidently at home in Paris, he did admit that the city has its fashion failings, stating "Bring with you lickways a pair of black silk stockings in you can get them good and cheap for they are very dear here" and "there is no cloath lick the Dutch black."45

Not surprisingly, Andrew Fletcher of Saltoun wore black himself, and he informed his nephew that he had "travelled from Bruxelles in my black sutt and since it has never bin off my back." ${ }^{46} \mathrm{He}$ was far from unique: indeed, as Michel Pastoreau observed, black clothes were a regular occurrence in the clothing choices of the sixteenth century Augsburg accountant, Matthäus Schwarz (1497-1574). ${ }^{47}$ However, Schwarz also tailored his wardrobe so that he could acknowledge and conform to local taste and fashions when he traveled to Milan and Venice in 1515 and $1516 .^{48}$ His son, Veit Konrad (1541-1587), followed suit when he went to Verona and Venice in $1556 .{ }^{49}$ Both men dressed in black Italian styles in order to succeed in business, and their choices reveal the

42 Murray, Letters, 166.

43 Ibid.

44 Ibid.

45 Murray, Letters, 166.

46 Ibid.

47 Pastoreau, Black, 99.

48 Ulinka Rublack and Maria Hayward (eds.): The First Book of Fashion. The Books of Clothes of Matthäus \& Veit Konrad Schwarz of Augsburg. London 2015, 75-80.

49 Ibid., 204-206. 
value of local knowledge that they, like Fletcher's nephew, accessed by asking family, friends, or business associates.

However, if conforming to local fashions while travelling was accepted as polite and prudent, was there a danger of going too far? James Howell, who was Welsh yet thought of himself as English when he wrote his Instructions for Forreine Travel (1642), noted how his countrymen "strive to degenerate as much as they can from Englishmen", which they did in a variety of ways, including the blending of language especially the Inglese Italiano. When he left home he changed "out of his country fashion, and indeed out of himself", while on his return he ought to "come home to himselfe, fashioned to such a carriage in his apparell, gesture, and conversation, as in his owne country is most plausible." 50 While this was a valid point of view, foreign fashions worn home were not always well received as revealed by the recollection of a call made by Lady Faudonside to Mr. Davidson with her son, John Ker. John was:

then ane young gentleman latelie come from France, pransing in his French garb, with his short scarlet cloake and his long caudie rapier, according to the mode of those tymes. ${ }^{51}$

As this example reveals, not everyone believed that fashion should cross borders: indeed, this was an example of a disapproving Scot who believed that French fashion should stay in France.

Traveling further afield potentially posed more challenges because, while European dress might be acceptable, in most quarters at least, William Feilding, first earl of Denbigh (1587-1643), might well have been regarded as “going native”. Feilding traveled to Persia and India between 1631 and 1633, and on his return he was painted by Sir Anthony van Dyck. ${ }^{52}$ He wore an Indian-style jacket that also incorporated elements of the fashionable doublet with loose "trousers" of the pyjamas type, while his native servant, called "Jacke", was dressed in a sherwani and turban. ${ }^{53}$ However, how far these were clothes for his portrait, as opposed to everyday wear once back in England, is hard to tell; nevertheless, they reveal a lasting interest in the clothing styles that Feilding had encountered on his travels.

50 Larkin, Making of Englishmen, 50.

51 Quoted in David Mathew: Scotland under Charles I. London 1955, 52.

52 Anthony van Dyck: William Feilding, 1st earl of Denbigh, 1633-1634, oil on canvas, 247.5 x $148.5 \mathrm{~cm}$, National Gallery, NG 5633.

53 Karen Hearn: Van Dyck \& Britan. London 2009, 98-99. 


\section{Black: The Mind-Set and Alternatives}

The second case study draws on the diary that Samuel Pepys kept during the 1660s because he provides invaluable insights into why and when he wore particular garments. ${ }^{54}$ Pepys is of interest because he was from the middling sort and at the height of his career he was Chief Secretary to the Admiralty, an office that gave him access to the court of Charles II. In 1660 Pepys traveled to the Netherlands in order to accompany Charles II back to England. While there, he bought Dutch clothes in order to integrate into society at The Hague. As such, he appreciated how to take on the style of another country in order to facilitate his current role; however, in the context of this discussion, it is what his diary reveals about the relationship with black clothing that is most important. Pepys shows that wearing black reflected a particular mind-set, and it could be habitual. In 1665 Pepys was evidently very comfortable wearing black because on 11 June he noted in his diary:

dressed myself in my late new black silk camelot suit; and when full ready, comes my new one of colour'd Farrinden, which my wife puts me out of love with; which vexes [me] but I think it is only my not being used to wear Colours which makes it look a little unusual upon me. ${ }^{55}$

He was not alone in noting problems with colored clothing. In 1716 Andrew Fletcher stated that:

if the heats be great about the time of your arrival, and you buy a coloured suttee, it must be of stuff, which will do you no service; and about the end of August a cloath lined with silk will be in Season. ${ }^{56}$

Pepys's discomfort in wearing colored clothing partially explains why he invested money in keeping his black clothes presentable. So on 30 March 1662, which was Easter Sunday, he commented "having my old black suit new furbished I was pretty neat in clothes today". ${ }^{57}$ Black had other benefits including allowing Pepys to dress down when required, as was the case on 15 November 1664: "that I might not be too fine for the business that I intend this day, I did leave off my fine cloth

54 For Pepys, see Claire Tomalin: Samuel Pepys. The Unequalled Self. London 2002. Also see Kay Staniland: Samuel Pepys and his Wardrobe, in: Costume 37 (2003), 41-50 and id.: Samuel Pepys and his Wardrobe, in: Costume 39 (2005), 53-63.

55 Latham and Matthews, Diary, vol. 6, 125.

56 Murray, Letters, 165.

57 Latham and Matthews, Diary, vol. 3, 54. 
new suit lined with plush and put on my poor black suit." ${ }^{\text {"5 }}$ On other occasions, black was combined with strong colors, as on 29 November 1663: "Lords Day This morning I put on my best black cloth suit trimmed with Scarlet ribbon, very neat, with my cloak lined with velvett and a new beaver, which altogether is very noble, with my black silk knit canons I bought a month ago."59 This combination of black and color was a common theme in men's wardrobe as two brief examples make clear. The first is a portrait of James Hamilton, Earl of Arran, Later 3rd Marquis of Hamilton painted in 1623 and his black suit contrasts strongly with his scarlet stockings. ${ }^{60}$ The second is the account for items bought by the laird of Glenorchy from James Rae in Edinburgh, 1639, that included the finest black satin, silver plate breast buttons, purple ribbons, Holland cloth, purple Spanish taffeta, and a fine black English hat. ${ }^{61}$

Pepys's diary also reveals that new clothes, including new black clothes, were often worn for the first time on a Sunday, as on 8 May 1664: "Lords day this day my new tailor, Mr Langford, brought me home a new black cloth suit and cloak lined with silk moyre." ${ }^{2}$ While black was well suited to a day of prayer and spiritual reflection, other factors influenced Pepys's choices, including the opportunity to show off new clothes, as he did on 10 May 1663: "put on a black cloth suit with white lynings under all, as the fashion is to wear, to appear under the breeches." ${ }^{63}$ He also often wore his best clothes as on 17 April 1664: "I put on my best cloth black suit and my velvet cloak."64

Fashionable black garments could be worn as mourning or worn with other items of mourning as on 11 February 1666: "Lords day - put on a new black cloth suit to an old coat that I make to be in mourning at court, where they are all for the king of Spain." 65 A few months later Pepys was in official, court mourning again, and he noted on 22 April 1666: "Lords day - put on my new black cloak-coat; long, down to my knees and with Sir W Batten to White-hall where all in deep mourning for the queen's mother."66

58 Ibid., vol. 5, 322.

59 Ibid., vol. 4, 400.

60 Daniel Mytens: James Hamilton, 3rd Marquis and 1st Duke of Hamilton, 1623, oil on canvas, 200.7 x $125.1 \mathrm{~cm}$, Tate Britain, NO3474, Presented by Colin Agnew and Charles Romer Williams, 1919.

61 Miscellaneous receipts, account due by the laird of Glenorchy to James Rae, merchant, burgess of Edinburgh, 1639. Paid 23 January 1640, GD112/29/15, no. 36 (National Records of Scotland).

62 Latham and Matthews, Diary, vol. 5, 144.

63 Ibid., vol. 4, 130.

64 Ibid., vol. 5, 125.

65 Ibid., vol. 7, 39.

66 Ibid., vol. 7, 106. 
As Pepys indicates, black was a frequent choice when getting dressed because it allowed him to present himself in so many different ways that were suited to the occasion. He was not alone in understanding the value of well chosen black garments. In 1703 Nicholas Blundell (1669-1737), who was a member of a recusant family, and who had been educated at the Jesuit College in St Omer, was considering marriage. ${ }^{67}$ He arranged to visit Heythrop Park, Oxfordshire, the home of Sir John Webb, with hopes of marrying Frances, daughter of Marmaduke, third lord Langdale and granddaughter of Lady Webb. Before setting out, he went on 12 April "to Liverpool to have a black coat made by Edward Porter for my journey to Heythrop". 68 The sober coat must have worked because on 28 April Nicholas "presented my diamond ring" and in May he "presented my gilt coffee spoons". ${ }^{9}$ On 3 June he bought a wedding ring in London, and on 11 June he "tried on my wedding suit there". ${ }^{70}$ The implication is that his London-made wedding suit was not black and a similar pattern can be seen in the choices of William Hamilton, third duke of Hamilton (1634-1694). For instance, on 19 August 1690 James Marshall wrote to Mr. David Crawforde, reporting that he had shipped from London the duke of Hamilton's "black suit and vest, two plaine musline cravates and 2 p[ai]r of rufles and a p[ai]r of best black silk stockings". ${ }^{71}$ While black suits served many purposes, when the duke wanted to demonstrate his loyalty to William III and Mary II he wore "a new sute with gold buttons and brocade wastcoat to complement his majestie with" while attending the king's birthday ball. ${ }^{72}$

Alternatives to black included grey, such as the fine grey Spanish cloth bought by the laird of Glenorchy from James Campbell in November $1657 .{ }^{73}$ While subdued, "sad colour" was evidently desirable, as is indicated by the purchase of sad-colored silk for a pair of breeches, a large skin for pockets, and a pair of clothcolored stockings for the young laird of Glenorchy from Alexander Rankene, merchant in Perth, in the early 1670 s. $^{74}$ In the same period, the accounts by Pitfoddels

67 Ralph Houlbrooke (ed.): English Family Life. An Anthology from Diaries. Oxford 1988, 243.

68 Frank Tyrer and John J. Bagley (eds.): The Great Diurnal of Nicholas Blundell of Little Crosby, Lancashire, vol. 1. Chester 1968, 31-38.

69 Ibid., 41.

70 Ibid., 42. They were married on 17 June, ibid., 43.

71 James Marshall, London, to Mr. David Crawforde, 19 August 1690, GD406/1/3679 (National Records of Scotland).

72 Marshall, Conscience, 33.

73 Accounts of special interest, account for tailoring due by the laird of Glenorchy to James Campbell, 22 November 1657, GD112/35/10, no. 12 (National Records of Scotland).

74 Miscellaneous receipts, account due by the laird of Glenorchy to Alexander Rankene, merchant in Perth, 1671-1673, paid on precept, 6 January 1674, GD112/29/30, no. 1 (National Records of Scotland). 
to Andrew Dempster included a sad cloth coat to the lord. ${ }^{75}$ Sad-colored fabrics could also reflect fashionable change as in the 18 yards of new sad-colored and black-striped silk bought by the duchess of Hamilton from Thomas Aliborne, from the "Hen and Chickings" in Covent Garden. ${ }^{76}$ As Pepys, Blundell, and Hamilton demonstrate, black was a safe yet sophisticated choice for men that held true across national and social boundaries.

\section{The Sense of a Scots Community}

Seventeenth-century Scots traveled widely in Europe for business, education and leisure, but there were some places where they congregated such as Veere, Leiden, and Saumur. ${ }^{77}$ This resulted in a sense of community, as can be seen in the letter of Annabella Lothian, who was living in La Rochelle in March 1649. She wrote:

It is hard to receaue lettres now since passages for the most pairte ar stopped from Paris so ye may wret with the ships that cumes ather to bourdeous or the Rochell derecting your lettres to bourdeous to Mr broun there and to the Rochell to Mr Masson, no scots cume to ather of those pairts that knows not those two men. ${ }^{78}$

While the Scots in these communities were bound together by ties of kinship and business, they also integrated with the local population by means of trade, marriage, and a shared religious outlook. At the Scottish staple at Veere, the former cloth merchant from Dundee, Sir William Davidson of Curriehill (1615-1689), became Conservator and agent of Charles II. $^{79}$ He married a local woman and

75 Accounts for tailoring due by Pitfoddels to Andrew Dempster, 1671-1672, GD237/11/96, no. 2-3 (National Records of Scotland).

76 Thomas Aliborne, from the hen and Chickings in Covent Garden, to the duchess of Hamilton, 15 May 1690, GD406/1/3683 (National Records of Scotland).

77 See Douglas Catterall: Community without Borders. Scots, Migrants and the Changing Face of Power in the Dutch Republic, c. 1600-1700. Boston 2002; Alexia Grosjean and Steve Murdoch: Scottish Communities Abroad in the Early Modern Period. Leiden 2005 and Steve Murdoch: Network North: Scottish Kin, Commercial and Covert Associations in Northern Europe, 1603-1746. Leiden 2006.

78 Annabella, countess dowager of Lothian, to the countess of Lothian, 16/6 March 1649, GD40/2/3, no. 1 (National Records of Scotland).

79 For Davidson's predecessor, see Victor Enthoven: Thomas Cunningham (1604-1669). Conservator of the Scottish Court at Veere, in: David Dickson et al (eds.): Irish and Scottish Mercantile Networks in Europe and Overseas in the Seventeenth and Eighteenth Centuries. Gent 2007, 39-66. 
dressed in the Netherlandish style, with his white linen contrasting against the black of his clothes. ${ }^{80}$

Gravitating towards local Scottish communities in Europe was not always an advantage for the Scottish traveler. In December 1678 Lord William Hamilton wrote to the duke of Hamilton, explaining that although "your Grace desired that I might not be known at Poitiers", this was impossible, "by reason of there being severall Scotts and Inglish students here who at my verie first appearing knew me." 81 However, these communities were always shifting in composition and dressing the part could only make a person fit in so far. This is evident from the letter sent by James Fall to the duke of Hamilton, explaining that he and his fellow countrymen will leave Paris soon and Lord William wants William Hamilton sent over to look after him, for "it very much weights his spirit to be left among strangers." 82

\section{The Verbal Virtues of Black}

An English royalist, John Bargrave, who traveled extensively, advised fellow travelers that "If his apparel be fashionably, it matters not how plain it be, it being a ridiculous vanity to go gaudy amongst strangers." 83 The language that Bargrave used to justify a particular style is reminiscent of that used by Castiglione, and it can be found running throughout sixteenth- and seventeenth-century correspondence. In March 1676, William, third duke of Hamilton, informed his son James, earl of Arran, that he was:

to be governed and follow his advice [Mr. Forbes] as absolutly as if it wer mine, and if in the least you faill in it [...] I intend imediatly on the knowledge therof to call you home. ${ }^{84}$

80 Abraham Lambertsz van den Tempel: Sir William Davidson of Curriehill with his Son Charles, c. 1664, oil on canvas, 140 x 108 cm, National Galleries of Scotland, acc. no. 2462.

81 Lord William Hamilton, Poitiers, to the duke of Hamilton, 13 December 1678, GD406/1/6125 (National Records of Scotland).

82 James Fall, Paris, to the duke of Hamilton, 6 September 1681, GD406/1/6197, (National Records of Scotland).

83 Travel journal of John Bargrave, un-foliated, Lit MS/E/39, Canterbury Cathedral Archives and Library.

84 The duke of Hamilton, London, to James, earl of Arran, 29 March 1676, GD406/1/5878 (National Records of Scotland). 
Later in the year the duke objected to James engaging "in things unfit for you, as balls, masquerades, unnecessary clothes and tennis". ${ }^{85}$ As a result Mr. Forbes tried to reassure the duke that once in Paris James's clothes would be "neither rich nor gaudy, but plain and fashionable". 86

A very similar use of language runs through the third case study, which considers the letters sent by Michael Young, tutor and companion to the two eldest sons of William, third earl of Lothian: Robert, lord Kerr of Newbattle, aged 15, and William, aged $12 .^{87}$ When confronted with more flamboyance than they were used to, dressing in that style was justified in several ways. The first option was to blame the locals. In December 1651 Michael Young wrote from Leiden stating that "the students here are very gallant in apparel. Beyond what they used to be in any part of France", but all was well because "it is more difficult to restrain Lord Kerr from buying books than clothes." 88 The second possibility was to cite court etiquette. This worked when the boys visited the Stuarts resident at The Hague where:

The fashion of the country did requyre that the Gentlemen should be clothed after that maner which though [it] may appear a little beyond what is ordinary in our Countrey yet it was very sober in respect of what is usual in Holland. ${ }^{89}$

Here, a combination of honoring local fashionable styles while showing their loyalty to the exiled Stuarts justified additional expense on suitable clothes. Young was not the only Scot writing home and he had to defend how his charges were dressed when their father announced that his sons "have been reported very fyn in their Clothes". Young refuted this claim by recourse to the language of Castiglione, stating that "Their fynnesse was never any other than a decent neatnesse [...] their Clothes being always very sober." This was backed up with a reminder that his Lordship had kept them so short of money that "wee could very scarcely doe of prodigality or gaudienesse in apparell". 90

85 Rosalind Marshall: The Days of Duchess Anne. Life in the Household of the Duchess of Hamilton, 1656-1716. London 1973, 136.

86 Marshall, Days of Duchess Anne, 138.

87 Margaret F. Moore: The Education of a Scottish Nobleman's Sons in the Seventeenth Century, in: Scottish Historical Review 31 (1952), 1-15.

88 Michael Young to the countess of Lothian, 30/20 December 1651, GD40/2/3, no. 7 (National Records of Scotland).

89 Note of accounts from March 25/15 1651 until March 25/15 1652, GD40/2/3/61B (National Records of Scotland).

90 Michael Young to Lothian, 8/18 February 1654, GD40/2/3, no. 27 (National Records of Scotland). 
A third option was to invoke a language of thrift, as in December 1651, when Michael Young assured Lord Lothian that:

it is fit each of them have ane spare suit handsomely mounted besides their sommer and winder suits as the seasons come about and ye fashion of the place requyreth. We shall indeavour that wee be prodigul in nothing. ${ }^{91}$

He used the same phrase, "sordid nor prodigall", earlier in the year, indicating that this was an effective phrase. ${ }^{92}$ Three years later Young informed the countess of Lothian that her sons "will be as frugal as honesty permits, but their suits, though plain, must be in the fashion with ribbons and other things." ${ }^{93}$

While the color of their clothes was usually not mentioned, some black items were specified including a black suit and black stockings. ${ }^{94}$ At Paris "wee bought only a Black broydered Belt and a Hat for my L Kerr, both were very necessair and though wee know that men doe not goo naked at Saumur, yet wee finde that many of them doe send for such things as those from Paris." ${ }^{\circ 5}$ However, other evidence suggests that black was not the norm because when their grandmother died in 1652 and their grandfather died in 1656 they did not have suitable clothing. That this was so is clear from a letter that Lord Kerr wrote to his mother in 1652: "If you think fit Madam that wee put our selves in murning, you will command us with the first and inable us to doe soe for as present it is not in our power." 96

Mourning clothes were to be found across Europe, and the underlying ideas cut across national boundaries. Here, too, the style of language that Castiglione used permeated discussions of how mourning clothes should look. Emphasis was placed on the depth of shade, the blackness of the black, in tandem with a lack of decoration and shine, as a physical demonstration of their sense of loss. While resident in Utrecht, Colin Campbell received news of his mother's death in January 1700, and he was anxious to reassure his father that he

91 Michael Young to Lothian, 12/2 December 1651, GD40/2/3, no. 6 (National Records of Scotland). 92 Michael Young to Lothian, 27/17 May 1651, GD40/2/3, no. 13 (National Records of Scotland). 93 Michael Young to the countess of Lothian, 26 October/5 November 1654, GD40/2/3, no. 40 (National Records of Scotland).

94 Detailed notes of expenses during absence abroad, GD40/2/3/61G (National Records of Scotland).

95 Michael Young to the countess of Lothian, end of January 1654, GD40/2/3, no. 25 (National Records of Scotland).

96 Lord Kerr to the countess of Lothian, 24 October/4 September 1652, GD40/2/3, no. 57 (National Records of Scotland). 
had "put John and my self in as deep mourning as if I had been on the place" [i.e. in Scotland]. ${ }^{97}$ The word "deep" recurred in a letter sent by David Monro, in December 1708, when he described a black mourning suit that was "deep enough for any accept a wife, father or mother". 98 The Laird of Glenorchy's response to the death of his daughter-in-law, Frances, who died on 4 February 1691, indicates that while he mourned her, dressed in the black clothing ordered specially for the occasion, life went on, and by mid February he sent for gray clothes for "death coms in at on dore \& hearshipe at the other."

\section{Conclusions}

As this brief discussion suggests, a black suit was acceptable anywhere in sixteenth- and seventeenth-century northern Europe, but to really fit in, it needed to reflect local fashions in terms of cut and decoration. As such, the black suit was a staple item in a wealthy man's wardrobe, regardless of where he lived. However, it would be rare that all his suits were black; if there was a preponderance of black, it was often offset by colored trimmings, white lace, and metal buttons. The value and virtue of the black suit was linked to the language used to describe it. While words such as "sobriety" and "not gaudy" conjured up a language of the subdued, this was tempered by a desire for fashionability and elegance. The challenge here was that all of these qualities were in the eye of the beholder, with one man's "sobriety" being another's flamboyance. Ultimately, the value of travel was reflected in this wish to embrace local styles in order to know how to dress when they returned home. Lord Ancram summed this up well when he wrote to the marquis of Lothian in the 1650s:

rather than to loyter at home or sculk in the Highlands especially in these winter warres' that the boys should go to Paris 'to perfyte their fencing and other manly qualityes, whereof they may yet have use when all these storms are over. But by any means do not forbid, but allow them to follow their dauncing with best masters at Paris, where they must spend tyme. They cum [from] home to get the right garb of the world. ${ }^{100}$

97 Colin Campbell of Ardmaddy, Utrecht, to Breadalbane, his father, 22 January 1700, GD112/ 39/181/3 (National Records of Scotland).

98 David Monro, Edinburgh, not addressed, 29 December 1708, GD157/2790 (National Records of Scotland).

99 Breadalbane to Carwhin, February 13 or 15 February, n.y. GD112/39/151/17 (National Records of Scotland).

100 Quoted in Moore, Education, 15. 